\title{
Judge's Consideration of the Custody to a Husband (Research at the Syar'iȳah Tapaktuan Court)
}

\author{
Sufyan Ilyas \\ Tapaktuan State Islamic Collage \\ Sufyan.ilyas@ymail.com
}

\begin{abstract}
This research deals with Judge's Consideration of the Provision of Parental Rights to a Husband (Research at the Syar'iȳah Tapaktuan Court). This research used qualitative research approach that emphasizes quality in accordance with descriptive understanding. This research is in the form of an analysis of cases relating to consideration of the judge of the provision of custody of minors to their husbands. The findings show that the problem of custody of minors is given to the husband must prioritize the interests of the child. Not based on who is more entitled or not, but with a number of reasons that benefit the child. By putting forward psychological and psychological factors the child becomes the most important part for bagiakim in giving decisions on custody of minors. In the case of child care that must be considered solely the interests of the child and have the ability and ability to provide security to the child.
\end{abstract}

Keywords : Custody; Court and Judge's Consideration.

\section{Introduction}

Marriage is an inner and outer bond between a man and woman as husband and wife with the aim of forming a family or a happy, eternal household based on God Almighty. In the Compilation of Islamic Law, marriage in Islam is also called marriage, namely a very strong contract or miśaqan galiźan to obey Allah's orders and carry out it is a worship that aims to realize the sakinah, mawadddah, and rahmah household life.

Basically the marriage is carried out for ever and ever until the death of one husband or wife. This is actually what the Islamic religion wants. But in certain circumstances there are things that require the termination of the marriage in the sense that if the marital relationship continues, then death will occur. In this case Islam justifies the termination of marriage as the last step in the effort to continue the household. The breakup of marriage is thus a good solution.

The Qur'an describes a number of situations in the life of a husband and wife that indicate a break in the household that can lead to divorce. Divorce is the breakup of the marital relationship between husband and wife, which is due to the absence of compatibility with each other. In Islam the principle of divorce is prohibited. That way God anticipates the possibility of divorce and puts the divorce as the last alternative that cannot be avoided

From year to year divorce rates in Aceh continued to increase after the tsunami. Based on the records of the Aceh Syar'iahah Court, in 2014 for example, out of 4,801 applications for divorce, 3,457 applications were submitted by the woman. In 2015 it was even higher, out of 5,300 divorce applications, 3,850 of them were submitted by wives. Based on the records of the Aceh Syar'iahah Court, there were 5,300 couples registering divorce applications in 2015. That means, the number of people who want to divorce in Aceh reaches 13 percent compared to residents who want to build a household. So based on data from the Syar'iyah Court of Aceh. Divorce cases that occurred in Aceh increased from year to year. 
Law number 23 of 2002 concerning Child Protection (hereinafter referred to as the Child Protection Act) only regulates foster power and this can be revoked if parents are known to abandon children or cannot guarantee the child's growth and development.

According to Law Number 1 Year 1974 article 9 paragraph (1) it is stated that one or both parents can lose their power over a child or more for a certain time or at the request of another person, the child's family in a straight line up and siblings who have adult or authorized official. With court decisions on matters:

1. He greatly neglects his obligations to his child.

2. He behaves very badly.

So in the case of child custody (haḍhānah) given to the mother who behaves badly, it may fall and can be given to the family of the upward line from the mother's side such as the grandmother of the mother's sister, daughter of a sibling / or male a thousand and a father, or aunt who is with mother, and so on. If you can't keep it or no one does custody at the women's level, then child custody can be given to his father's side, the line up or the authorities, namely the government.

Based on the above problems, underage parenting rights are the rights of his mother which turned out to be in practice and in theory different from the ruling set by the Syar'iah Court. Because a mother neglects her obligations as a mother to her child and a misbehaving mother who is not in accordance with what is taught by Allah's commands.

Then the causes like that will bring harm to children mentally, morally and religiously. Because there is a sense of concern for a father when custody is given to his mother, he will follow the behavior of the mother who is not in accordance with his teachings.

However, the decision of the Tapaktuan Syar'i'ah Court Judge in child custody cases (haḍhānah) number 0144 / Pdt.G / 2015 / MS.Ttn that the maintenance of underage children falls on the side of the husband not on the side of the wife, as stipulated in article 105 letters (a) jo Compilation of Islamic Law (KHI).

\section{Theoretical Review}

\subsection{Child Custody in Islamic Law}

In Arabic, the term parenting is called al-hadhānah which comes from the origin of the word al-hidhn something that is placed between the armpits and hips'. The sentence, "hidhna ash-syai'a," means "we put something above the hip (carrying). "The phrase" hadhana ath tha'iru baidahu, "means," A bird flanks its egg under its wings. "And the sentence," hadhanat al-mar'atu waladaha "means a woman holds her child".

"Child Custody" comes from Arabic which has meanings, among others: the matter of maintaining, educating, regulating, managing all interests / affairs of children who have not yet been mumayiz (unable to distinguish between good and bad things or actions for themselves).

"Child custody", according to language means putting something near the ribs or lap, because the mother when breastfeeding her child puts the child in his lap, as if the mother at that time protects and cares for her child, so "ḥaḍhānah" is used as the term: "Education and maintenance of children from birth to being able to stand alone takes care of themselves carried out by the child's relatives". While terminologically, child custody is caring for and 
educating a child who has not been mumayiz or who has lost his intelligence, because they cannot fulfill their needs.

Jurisprudence scholars define "Child Custody" as an act of caring for young children, both male and female or who are already big but not yet mumayiz, providing something that makes their good, keeping it from something that hurts and destroys it, educates the body, spirituality and reason, to be able to stand alone to face life and assume responsibility.

In terms of fiqh two words are used but are intended for the same purpose, namely "kaffalah" and "child custody". What is meant by "child custody" or "kaffalah" in the simplest sense is "maintenance or care".

In a more complete sense, it is the maintenance of young children after a marriage breakup. This is discussed in fiqh because practically the separation between husband and wife has occurred, while children need help from their father and / or mother. Parents are obliged to finance their small children not only applies to fathers and mothers who are still bound by marriage, but continue after the divorce.

\subsection{Child Custody in Positive Law}

Child custody in question is the obligation of parents to maintain and educate their children as well as possible. This maintenance covers the problem of education and everything that becomes basic needs of cyanak.

In the Civil Code in Indonesia, it is said that child custody is to maintain a child who has not been able to live independently which includes education and everything he needs in the form of implementing and in the form of avoiding something that can damage it.

Furthermore, the responsibility of maintaining children in the form of supervision and service as well as the adequacy of these children's livelihoods is sustainable until the child has a legal age limit as a mumayyiz who has been able to stand alone.

Whereas what is meant by education is the obligation of parents to provide education and teaching that enables the child to become a human who has the ability and dedication to live according to the child's talent that will be developed in the midst of Indonesian society as the foundation for his life and livelihood answered his parents.

In Law No. 23 of 2002 concerning Child Protection mentioned: Article 1

(2) Child protection is all activities to guarantee and protect children and their rights to be able to live, grow and participate optimally in accordance with the dignity of humanity, and get protection from violence and discrimination. Article 8

Every child has the right to obtain health services and social security in accordance Article 13

with physical, mental, spiritual and social needs.

(1) Every child during the care of parents, guardians, or any other party responsible for care, is entitled to protection from treatment:
a. discrimination;
b. exploitation, both economic and sexual;
c. neglect;
d. cruelty, violence and persecution;
e. injustice
f. other mistreatment. 
(2) In the event that a parent, guardian or caregiver of the child carries out all forms of treatment as referred to in paragraph (1), the offender is subject to a "penalty" Article 16 weight.

(a) Every child has the right to receive protection and targets for persecution, torture, or imposition of inhuman punishment.

(b) Every child has the right to obtain freedom according to law.

(c) Arrest, detention or criminal offense of child imprisonment is only carried out if it is in accordance with what is valid and only done as a last resort.

Article 26

(1) Parents are obliged and responsible for:

a. Parenting, educating, and protecting children.

b. Grow children according to the abilities of their talents and interests.

c. Preventing marriage at the age of the child.

(2) In the event that a parent does not exist or because of an obligation and responsibility, the obligations and responsibilities as referred to in paragraph (1) can be transferred to the family, which is carried out in accordance with the

Article 36 applicable legal provisions.

a. In the event that the appointed guardian turns out that in the future he is incapable of carrying out a legal act or misusing his power as a guardian, then his guardianship status shall be revoked and appointed by another person as guardian through the establishment of a court.

b. In the event that the guardian dies, another person is appointed as guardian through the determination of the court.

Article 14 of Law Number 23 concerning child protection which states: every child has the right to be cared for by his own parents, unless there is a reason / and or rule that is valid indicates that the separation is in the best interest of the child and is the final consideration. In his explanation, it was emphasized that "the separation referred to in this provision does not eliminate the relationship between children and their parents." So even though there are provisions that state one parent as the holder of "child custody", there is no reason to forbid parents to meet their children.

In the explanation of Law Number 23 of 2002 concerning Child Protection, it affirms: "That the responsibility of parents, family, community, government and state is a series of activities carried out continuously for protection and direction to ensure the growth and development of children both physically and physically. mental, spiritual and social.

\subsection{Child Custody in Law No. 1 of 1974}

Basically the responsibility of caring for children is a burden on both parents, both parents still live in harmony or their marriage fails due to divorce. In Law No. 1 of 1974 there are several articles which explain the rights and obligations of parents and children as stated in Article 41 of Law No. 1 of 1974 concerning marriage stating that:

1. Both the mother and father are still obliged to care for and educate their children, solely based on the interests of the child, if there is a dispute regarding the prosecution of the children of the court giving their decision. 
2. The father who is responsible for all the maintenance and education costs required by the child, if the father is in fact unable to fulfill these obligations, the court can determine that the mother is involved in carrying (bearing) the costs for the child.

3. Courts can require ex-husbands to provide living expenses and / or obligations for exwives. $^{1}$

Based on the article, it can be seen that both the mother and father are still obliged to care for and educate their children, solely based on the interests of the child. If there is a dispute regarding the control of children, it is resolved through a court decision. In this case the question is who is more entitled whether a father or mother has not been explained because, if based on article 41 letter a, the court has an important role in giving authority to custody of someone. So to know who and why an imimim is giving custody, it must be assessed through consideration of the imakim decision on a matter. Article 45 states that:

1. Both Parents must maintain and educate their children as well as possible.

2. The Parental Obligation referred to in paragraph (1) of this article is valid until the child marries or can stand alone, the obligation continues even though the marriage of the parents breaks up. ${ }^{2}$

Furthermore, also explained articles 47 and 48 concerning the rights and obligations of Parents and Children.

1. Children who have not reached the age of 18 years or have never married are under the control of their parents as long as they are not revoked from their power.

2. Parents represent the child regarding acts of law inside and outside the Court.

\subsection{Child Custody in the Compilation of Islamic Law}

As for the Compilation of Islamic Law (KHI) the definition of child custody as well has been formulated in article 1 letter $(\mathrm{g})$ that what is meant by maintenance and educating children to adulthood or being able to stand alone.

In Compilation Chapter XIV article 98 is explained as follows:

1. The age limit of a child who is able to stand alone or is an adult is 21 years, as long as the child is not physically or mentally flawed or has never had a marriage.

2. His parents represent the child regarding all acts of law within and outside the court.

3. The Religious Court can appoint one of the closest relatives who are able to fulfill the obligation if both of their parents die.

The article implies that the obligation of both parents is to deliver their children, by educating them, to equip them with knowledge to prepare them for adult days.

\section{Research Method}

The research approach used in this study is a qualitative research approach, namely research that emphasizes quality in accordance with descriptive understanding. This research is in the form of an analysis of cases relating to consideration of the judge of the provision of custody of minors to their husbands.

\footnotetext{
${ }^{1}$ Amiur Nuruddin and Azhari Akmal Tarigan, Hukum Perdata Islām di Indonesia, Studi Kritis Perkembangan Hukum Islām dari Fikih UU No 1/ 1974 sampai KHI, (Jakarta : Kencana, 2006), page. 299.

${ }^{2}$ Ibid, page. 299
} 
The overall research time was carried out for two weeks in January 2017. The research site at the Syar'iȳah Tapaktuan Court Office, Air Berudang Village, Tapaktuan District, South Aceh Regency.

\section{Discussions}

From the results of research on data obtained through documentation studies in the form of child custody decisions. Then the data that has been obtained can be concluded that the problem of custody of minors is given to the husband must put the interests of the child first. Not based on who is more entitled or not, but with a number of reasons that benefit the child. By putting forward psychological and psychological factors the child becomes the most important part for bagiakim in giving decisions on custody of minors.

\subsection{Factors Causes of Underage Child Custody Rights to Husband}

Has given bad teaching to his child, because since childhood he has witnessed his mother dating, having an affair with another man while his mother is still tied to marriage with his father. ${ }^{3}$

Based on the decision Number 0144 / Pdt.G / 2015 / MS.Ttn in cases of child custody claims (haḍhānah) include: Mansur Supardi bin. M. Nasir, age 35, Islam, Private Work, residence of Meunasah Hamlet, Central Kreung Batee Village, Kuala Batee Sub-District, Southwest Aceh District, hereinafter referred to as the Plaintiff. Against Fatriani bint Jakfar, age 32, Islam, work did not work, the residence of the Meunasah Tengah Hamlet, Krueng Batee Village, hereinafter referred to as the Defendant.

Sit the case

a. That the Plaintiff (Mansur Supardi bin M. Nasir) had a legal relationship as husband and wife with the Defendant (Fatriani binti Jakfar) and was divorced by the Tapaktuan Syar'iyāh Court on March 3, 2015 (12 Jumadil 1436) based on the Tapaktuan Syar'iyāh Court Decision, South Aceh Regency Number: 0201 / Pdt.G / 2014 / MS.Ttn.

b. Whereas in the marriage the Plaintiff and Defendant was born a legitimate child named Maulija Sufarija in Krueng Batee District, on March 3, 2009.

c. That at the time the Defendant (Fatriani Binti Jakfar) was still bound by a legitimate husband and wife relationship with the Plaintiff (Mansur Supardi Bin M. Nasir) it was clearly seen that the Defendant (Fatriani binti Jakfar) was not a good mother, so it was not worthy parenting rights (ḥạ̣hānah) for Maulija Sufarida's children, because the Defendant often traveled and left the house at night with the aim of playing games and leaving Maulija Sufarida at home, even though the Plaintiff had advised and advised the family, but the defendant (Fatriani binti Jakfar) remains ignorant of the advice to maintain the miśaqan galiźan household as referred to in the Instruction of the President of the Republic of Indonesia Number 1 of 1991 concerning Compilation of Islamic Law.

d. That the Defendant (fatriani binti Jakfar) had given poor teaching to ananda Maulija Sufarida because since childhood she had witnessed her mother (fatriani bint Jakfar), dating, having an affair with other men, including brother Zul Baili bin Ibrahim, while Defendant (Fatriani bint Jakfar) still tied to marriage with the Plaintiff since many years before the divorce on March 3, 2015.

\footnotetext{
${ }^{3}$ Arsip Mahkamah Syar'iyāh Tapaktuan, Putusan Nomor: 0144/Pdt.G./2015/MS.Ttn.
} 
e. That illicit relations, infidelity and alleged adultery carried out by the Defendant (Fatriani binti Jakfar) with Zul Baili bin Ibrahim, was witnessed by ananda Maulija Sufarida. The Plaintiff even knew the first news of the Defendant's affair with other men, based on the information from Maulija Sufarida, which was very damaging to the development of spirit and moral education of Maulija Sufarida.

f. That before the divorce with Fatriani binti Jakfar, the Plaintiff had advised repeatedly not to go anywhere, like to go out at night, even though Ananda Maulija Sufarida was at home and stayed for days and nights, so as not to undermine the education of our only child named Ananda Maulija Sufarida, for having involved our child in an affair, but the Defendant ignored the Plaintiff's advice, for the good of Ananda Maulija Sufarida.

g. That the evidence of the Defendant's adultery with other men, can be seen from now that the Defendant has been in a state of pregnancy around 8 (eight) months, even if it is calculated from the time the Plaintiff was divorced by the Defendant by the Court of Justice on March 3, 2015, iddah three times holy (tsalatsa quru '), then as soon as possible the new Defendant may marry around 4 June 2015. Thus it can be ascertained that the Defendant's pregnancy currently reaches around 8 (eight) months is strongly suspected as a result of adultery. So the depravity of a mother's morals will greatly damage the development of education and psychology for the children of Maulija Sufarida, so that the Defendant is not worthy of being an educator (caregiver) for Ananda Maulija Sufarida.

h. That it deviates from the provisions of Article 105 letter (a) Compilation of Islamic law based on Presidential Instruction No. 1 of 1991, then repeatedly the Supreme Court jurisprudence. The Republic of Indonesia decided that; for the good of education and care for children who have not been mumayiz or are not yet 12 (twelve) years old, they can be handed over to their father (Plaintiff).

i. That the Plaintiff often saw the emotion of sadness or silence or the change in attitude of Maulija Sufarida due to getting a bad education received from her mother (Fatriani binti Jakfar), where ananda Maulija Sufarida saw her mother sleeping with another man about 5 (five) months in when the Defendant (Fatriani Binti Jakfar) is still bound by marriage to the Plaintiff.

j. That based on written data and authentic evidence that the Plaintiff immediately submitted, it was clearly illustrated that in the polygamous status and erratic work of Zul Baili, the Defendant was known at this time that the Defendant (Fatriani binti Jakfar) did not have a permanent residence and only living in a rented house, then making the fate and conditions of education and the future of Ananda Maulija Sufarida become shaken, moreover watching her mother Fatriani Binti Jakfar provide poor care and education and exemplary values that were very despicable to Maulija sufarida. Therefore it is in accordance with the intent and purpose of the law and for the realization of "substantive justice", please the Chairperson and the Syar'iyāh Court Judge Council provide child care rights (ḥaḍhānah) ananda Maulija Sufarida to the Plaintiff (Mansur Supardi bin M. Nasir).

k. That the Defendant's double marriage with Zul Baili's brother was carried out in the Percut Sei District Religious Affairs Office Mr. Jalan Besar Number 34 Tembung, Deli Serdang Regency, North Sumatra Province, based on the Defendant's marriage certificate with brother Zul Baili Number: 3684/401 / X / 2014, dated October 25, 2014.

1. That the head of Percut Sei Tuan District Religious Affairs Office has issued an official and original statement numbered kk.02.01.19 / PW.01 / 648/2015, dated April 7, 2015 which states / explains as follows: 
1) Husband; Zul Baili's name, place and date of birth; Krung Gak, 10-11-1974, Indonesian Citizen, Islamic Religion, Entrepreneurial Work, addresses Paya Penaga.

2) Wife; The name Patriani, place and date of birth December 11, 1982, Indonesian Citizen, Islamic Religion, Entrepreneurial Work, address Padang Seu Rehat.

The name above is a true husband and wife, married on Saturday, October 25, 2014 with the guardian of marriage Gafar (biological father). Their marriage was registered at the Office of Religious Affairs in Percut Sei Tuan Subdistrict, Deli Serdang Regency, with a marriage certificate number: 3684/401 / X / X / 2014.

$\mathrm{m}$. Based on the events of the law and the written facts of the authentic Plaintiff stated above, then the Plaintiff requests the Assembly of Judges who hear the case of the Aquo lawsuit to give the following verdict:

1) To grant a claim from Mansur Supardi bin M. Nasir throughout.

2) Establish, give parenting rights (haḍhānah) ananda Maulija Sufarida to the Plaintiff (Mansur Supardi bin M. Nasir).

3) If the Chairperson and the Council of Judges adjudicating the lawsuit in the Aquo case are of different opinion, then in another court, the Plaintiff requests fair justice.

\subsection{Judgment of the judgment of the provision of parental rights to a husband.}

Considering, that the fact was found in the trial that the child had now been submitted by the Defendant voluntarily to the Plaintiff and the child was calm and comfortable being in the care of the Plaintiff as his father. In addition, the Defendant did not object and did not question the child care rights to the Defendant, the Assembly of the judiciary argued that the Plaintiff's claim could be granted;

Considering, that when the Plaintiff's claim that the child custody (haḍhānah) of his child was determined to be reasonable for him to be granted, then it must not reduce the Defendant's rights and obligations as his biological mother to do his best for the sake of the child, such as visiting, helping educate as much as devote love to children;

Considering, that from the evidences found the facts which are basically as follows:

a. That the Plaintiff and Defendant are legitimate husband and wife and have been officially divorced on March 3, 2015;

b. That from the marriage results the Plaintiff and Defendant have been blessed with children named Maulija Sufarida, born on March 8, 2009;

c. That the defendant had handed the child over to the Plaintiff without any element of coercion;

d. That the Defendant had remarried and had only given birth to a child from the second marriage, so that the child named Maulija Sufarida received less attention and affection, and tended to be neglected in the care of the Defendant as his biological mother;

e. That the Plaintiff is a good and responsible father so that it is appropriate to take care of children;

Considering, that because the a quo case entered the field of marriage, then based on Article 89 paragraph (1) of Law Number 7 Year 1989 as amended by Act Number 3 of 2006 and the second amendment to Law Number 50 of 2009, the cost cases must be charged to the Plaintiff; 
In view of all the articles in the laws and regulations and the Islamic law relating to this case.

\section{PRESENT}

a. Declares that the Defendant has been officially summoned and is worthy to appear before the trial not present;

b. Grant the Plaintiff's claim verstek;

c. Establishing a child named Maulija Sufarida binti Mansur Supardi, age 5, under the haḍhānah (maintenance) of the Plaintiff;

d. Charges the Plaintiff to pay court fees in the amount of Rp.661,000 (six hundred and sixty one thousand rupiahs). ${ }^{4}$

In this case, the author agrees with what is stated as "judge in consideration of the law because if it is related to article 41 letter a of Law No. 1 of 1974 concerning marriage, it is stated that both the mother and father are obliged to care for and educate their children, solely based on the interests of the child, if there is a dispute regarding the control of the children of the court giving its decision.

The obligation of parents to children is also determined in article 45 of the Marriage Act No. 1 of 1974 concerning marriage stating that:

a. Both parents must maintain and educate their children as well as possible.

b. Parental obligations referred to in paragraph (1) of this article are valid until the child marries or stands alone, their obligations apply continuously even though the marriage between the two parents breaks up. ${ }^{5}$ Thus from the sound of the provisions in article 45 of Act Number 1 of 1974 concerning marriage, it means the responsibility and obligation of both parents towards their children to care for, nurture and educate and others are attached until their children are mature or able to stand own.

The connection with article 45 paragraph 1 of Law Number 1 Year 1974 concerning marriage emphasizes the word nurturing and educating children whose purpose is:

a. Maintain

About maintaining this has a very broad meaning. This law is the responsibility of parents to supervise, provide appropriate services and fulfill the life needs of a child by parents.

1) The responsibility for maintenance in the form of supervision and service as well as the adequacy of the child's livelihood is continuous until the child reaches the legal age limit as an adult who can stand alone.

Of the two elements of maintenance it is clear to us that the obligation is an ongoing responsibility until the child reaches the age limit that is truly mature and has matured to stand alone. The meaning of this maintenance includes supervision, service and spending in a broad sense. The author argues that maintenance in this case is similar to what is regulated in the "Islamic law, which is called haḍhānah.

b. Educating

In this case educating is providing education and teaching that enables the child to become a human who has the ability and dedication of life equipped with abilities and skills in accordance with the talents of the child who will be developed in the midst of the community as a foundation for life and livelihood after he is released from her parents.

\footnotetext{
${ }^{4}$ Arsip Mahkamah Syar'iyāh Tapaktuan, Putusan Nomor: 0144/Pdt.G./2015/MS.Ttn.

${ }^{5}$ Marriage Law Number 1 of 1974.
} 
With the best words, it is an emphasis so that maintenance and education at the same time include a combination of quantity and quality of maintenance and education so that the family as a joint arrangement that will become a unit of society as much as possible produce children who are cared for spiritually and physically.

The maintenance rights of children in Article 41 of Law No. 1 of 1974, even though the parents of the child are no longer together in this case divorce, both the mother and father are still obliged to educate and care for the child solely for the sake of cyanak. If a dispute arises regarding child custody, the 'Syar'i'ah Court Judge who will give his decision in accordance with the evidence and statements of the witnesses presented at the trial at the Syar'iȳah Court.

Other considerations given to the husband's child custody are that the Defendant has remarried and has only given birth to a child from the second marriage, so the child named Maulija Sufarida lacks attention and affection, and tends to be neglected in the care of the defendant as his biological mother.

\section{Conclusion}

The implementation of custody of the child for a divorced husband if the child is not yet mumayiz or the child is underage then his mother is more entitled than his father. But in carrying out child custody it is not easy because even though hadhin is the biological parent of the child does not mean he can simply be able to carry out child custody but he must also be trustworthy, Muslim, and have the will and ability to nurture and educate.

In the case of child care that must be considered solely the interests of the child and have the ability and ability to provide security to the child.

\section{References}

Abdul Majid Mahmud Mathlub. Panduan Hukum Keluarga Sakinah. Surakarta: Era Intermedia, 2005.

Aby Yazid, "Hadhanah Hak Asuh Anak" (on-line). 27 Februari 2008, access by web: http:// Abiyazid.wordpress.com. date 27 April 2016.

Ahmad Zamahsyari,"Pelimpahan Hak Asuh Anak Kepada Bapak (Studi Pengadilan Agama Jakarta Timur Perkara Nomor: 1829/ Pdt.G/2008/ PAJT) (on-line), 29 February 2012 access by web: .http://repository.uinjkt.ac.id. 27 April 2016.

Aliranim, Pengertian Dasar Hukum dan Syarat (on-line) 29 November 2014, access by web: http://aliranim.blogspot.co.id. 27 April

Almanhaj, hak pengasuhan anak dalam Islām demi kebaikan anak (on-line), 17 April 2017 access by web: https://almanhaj.or.id. 27 April 2017.

Amir Syarifuddin, Hukum Perkawinan Islam di indonesia, Antara Fikih Munakahat dan Undang- Undang Perkawinan, Jakarta: Kencana, 2011.

Amiur Nuruddin dan Azhari Akmal Tarigan, Hukum Perdata Islam di Indonesia, Studi Kritis Perkembangan Hukum Islam dari Fikih UU No 1/ 1974 sampai KHI, Jakarta: Kencana, 2006.

Asmudi, "Hak Hậhānah Kepada Ayah Dalam Perspektif Maqāşid Asy-syari'ah (Studi Terhadap Putusan Pengadilan Tinggi Agama Yogyakarta Nomor: 08/Pdt.G/ 2009/ PTA Yk (on-line), 12 April 2016, access by web: http://digilib.uin-suka.ac.id. 27 April 2016. 
Dendy Sugono, Kamus Besar Bahasa Indonesia, Jakarta: Pusat Bahasa 2008.

Departemen Agama R.I, Al-Qur'an with meaning, Jakarta:Derektorat Pembinaan Agama Islam 2007.

Indra Gunawan, Akibat PerceraianTerhadap Pengasuhan Anak Dibawah Umur Menurut Undang-Undang Nomor 1 Tahun 1974 Tentang Perkawinan (Studi Kasus Putusan Nomor: 1684/Pdt.G./2007/PN. Jak.Sel) (on-line), 15 may 2010, access by web: http://lib.ui.ac.id. 13 Maret 2017.

Kompilasi Hukum Islam.

Lilis Sumiyati, Murtad Sebagai Penghalang Hadhanah (on-line), 2 february 2016, access by web: http://repository.uinjkt.ac.id. 27 April 2016.

Maulana Ibroohim, Pelimpahan Hak Asuh Anak Kepada bapak Akibat Perceraian (on-line), 29 februari 2014, access by web: http:// repository uinjkt.ac id. 27 April 2016.

Muhammad Imamul Umam, "Hak Asuh Anak Dalam Perkara Cerai Talak Karena Istri Murtad (Studi Analisis Penetapan PA Nomor: 447/Pdt.G/2003/PA.SAL) (on-line), 4 maret 2016, access by web: http://perpus.iainsalatiga.ac.id, 27 April 2016.

Psikologi, Hak dan Kedudukan Anak Setelah Perceraian Orang Tuanya serta Kewajiban (online), 27 may 2016 http://www.landasanteori.com. 27 April 2016.

Rahima, Pandangan Islām tentang pengasuhan anak (Hadhanah); Suplemen Edisi 45, isi (online) 18 july 2014, access by web http:/l/ ww.rahima. or.id. 27 April 2016.

Risky, Teknik Analisi Data Kulitatif, Kuantitatii situsf Menurut Para Ahli (on-line) 7 desember 2016, access by web: http://pastiguna.com. 27 December 2016.

Rizqa Fitria, Jangan Tambah Lagi Angka Perceraian di Aceh (on-line), 15 February 2016, access by web: http://Aceh tribunnews.com. date 27 April 2016.

Sayyid Sabiq, Fiqih Sunnah 3, Jakarta: Pena Pundi Aksara, 2009.

Sayyid Sabiq, Fiqih Sunnah, translated by. Asep Sobari, Jakarta: Al-I'tishom, 2008.

Siti Nur Hidayati, Hak Asuh Anak Pasca Perceraian (on-line), 10 December 2012, access by web: http:// Kompasina.com. date 27 April 2016.

Sohari Sahrani, Fikih Munakahat Kajian Fiqih Nikah Lengkap Jakarta: Rajawali Pers, 2013.

Sulaiman Al-faifi, Mukhtashar Fiqih Sunnah Sayyid Sabiq2, Solo: Aqwam, 2010.

Sulaiman Rasyid, Fiq Islam,. Bandung: Sinar Baru Al-Gensindo, 2003.

Syaikh Shalih bin Fauzan Al-Fauzan, Hak Pengasuhan Anak Dalam Islam demi Kebaikan Anak (on-line), 18 April 2017 access by web: https://almanhaj.or.id. 27 April 2017.

Undang-Undang Perlindungan Anak, Number of 2002 about Perlindungan Anak, Jakarta: Sinar Grafika, 2012.

Undang-Undang Republik Indonesia Number 1 of 1974 about Marriage.

Zainuddin Ali, Hukum Perdata Islam di Indonesia, Jakarta: Sinar Grafika, 2012. 